\title{
Globalization and Democratization in Nigeria's Quest for Democratic Governance in the Fourth Republic
}

\author{
Yusuf Isma'ila' \\ Zaheruddin Othman² \\ College of Law, Government and International Studies, 06010 Sintok, Kedah, Universiti Utara, Malaysia182
}

\section{Doi:10.5901/mjss.2016.v7n1p386}

\begin{abstract}
Following the trend of global democratic change, Nigeria like many other developing countries struggle to abandon military rule for democracy. The fifteen years of fourth republic democratic experiment in Nigeria have been characterize with misfortunes of good democratic governance. Several efforts made to consolidate good democratic governance in the country were simply thrown away. The expectations of Nigerians in 1999 when democracy return after fifteen long years of military rule were high. However these expectations and optimism were unfortunately quashed. The paper critically investigates this situation and assess the challenges surrounding the quest for effective democratic governance in the country within the era of global democratic change. In conclusion the paper emphasize on restructuring attitudes, institutions and resources towards the principles of democratic governance.
\end{abstract}

Keywords: Globalization, Democratization, Democratic governance, Nigeria's' Fourth Republic

\section{Introduction}

Although macro-economic indicators appeared to have shown that achievement have been made since the return of democracy in Nigeria from $29^{\text {th }}$ may 1999 , several scholars and citizens strongly claimed that expectations were not met due largely to the flawed democratic processes. The fact that democratic institutions such as political parties, security operatives and electoral umpires' etcetera are not playing the rules of the game of democracy, confirms these claims. The insecurity of Nigerians and expatriates in the hands of Boko haram insurgency and Niger- Delta militants tells the story of the under achievements of the fourth republic democratic experiment. In fact high level political corruption, electoral malpractice, ethno-religious conflicts, unemployment and poverty became synonymous features of the Nigeria's fourth republic experience.

Following the trend of this situation this paper seeks to examine based on critical approach, the transformation of Nigeria's democratic decadence to a better path of good democratic governance. The question is why does Nigeria's fourth republic expectations thrown away?

\section{Conceptual Clarifications: Democracy, Democratization and Democratic Governance}

It is noteworthy to observe that both democratization and democratic governance originates from the concept of democracy. While the three concepts are interconnected, they are independently unique and distinct with different variables. For instance democracy is constitutional rule or government where people select amongst themselves representatives to discharge responsibilities concerning their welfarism and allocation of values and resources effectively. Democratization however is about movement or struggle by people to possess values of democracy, that is, to be able to work with the principles of democracy such as political parties, elections, constitutionalism, freedom and rights, etcetera in their system of politics or government. On the part of democratic governance thus, it is about functioning of those principles of democracy in a political system. It is therefore one thing to struggle or even have democracy, but it is entirely another different thing to have effective functioning of democratic processes or principles in a political system. Therefore in situation where institutions of democracy are vibrant and sustainable, democratic governance can be said to be in existence, however the absence of those characteristics can be considered as a doom for democratic governance. It is also significant to note that a comprehensive definition of the term democracy is conceptual as well as theoretical impossibility. Thus attempt by scholars and political theorists across age, discipline and society to defined democracy 
have always foundered on the rock of antiquity and antinomy. It has been noted that:

This profound epistemological impasse may be due to the fact that the concept of democracy itself is a process of perpetual becoming. The democratic ideal remain just that an ideal. Indeed the completely democratic society is a political and historical mirage (Williams, 1995:65).

Despite difficulties and compounded intellectual and ideological differences to bring about concise and precise definition of democracy, scholars and researchers have resorted to various device and stratagems for highlighting its often contradictory actualities. Perhaps following the lead of Robert Dahl (1971) in his seminal contribution, "Polyarchy" Diamond, et al have defined the term as a system of government which is characterized with three ingredients, which are as follows;

\begin{abstract}
Meaningful and extensive competitions among individuals and groups (especially political parties) for all effective positions of government power, at regular intervals and excluding the use of force; a highly inclusive level of civil and political participation in the selection of leaders and policies, at least through regular and fair election such that no major (adult) social group is excluded; and a level of civil and political liberties freedom of expression freedom of press, freedom to form and join organizations sufficient to ensure the integrity of political competition and participation (Cited in Diamond, 1992: 14-15).
\end{abstract}

Thus, it is along the line of this definition that Diamond opined that global democratic revolution and the trend it has taken could be measured. A country can be measured or described as democratic if it combines must of the features mentioned or highlighted in the definition, especially - freedom of speech, freedom of association, the supremacy of the will of the electorate, regular elections, and accountability. A country is thus semi democratic if it combines some of these features and undemocratic if its polity is marked by singular absence of most or all of the features.

In the liberal perspective of democracy, Ojie (2006) describes democracy in the following words:

The essential idea of democracy is that the people have the right to determine who governs them. In most cases they elect principle governing officials and hold them accountable for their action. Democracy also impose legal limit on the government's authority by guaranteeing certain rights and freedom to their citizens (Cited in Ebirim, 2014:3).

"Any regime where the consent of people is sought to be obtained without freedom of expression of divergent opinions, does not qualify for being called democracy even if it maintains certain democratic institutions" (ibid: 5).

Using quantitative method Potter, Goldblatt, Kiloh and Lewis (1997) observed that "Democratization" is the main global phenomenon in the twentieth century. It spreads with particular vigor since the 1970s; in 1975 at least 68 percent of countries throughout the world were authoritarian, all the rest having held some sort of political and civil rights. In their book "Democratization" potter et al, (1997) examines, "the word Democratization refers to political change moving in democratic direction" they explained why some political regimes move in a democratic direction than others? They further explained what is meant by "moving in democratic direction and how one identify actual political regimes throughout the world as a more or less democratic".

Potter et al's formulation of democratization rests on a set of seven concepts grounded for the most part of David Held's (1976) models of democracy and Robert Dahl's (1989) democracy and its critics. They distinguish five main types of political regimes. They distinguished this typology regime to different attribute of state and civil society. The state is characterized by assembly of an institutional patterns and political organizations, coercive administrative, legaldistinguished from other organizations in society by having the capacity to monopolize the legitimate use of violence within a giving territory. Each state also aims to provide security from foreign intervention for people within its boundaries by conducting relations, both peaceful and war like, with other states. On the other hand, the concept of civil society is distinct from the state and can be said to name the space of unforced human association and also the set of relational networks-framed for the sake of family, faith, interest and ideology. Civil society can be harsh or sparse in terms of the number and vitality of association and relational networks within state boundaries. It is important not to see the state at totally 'separate' or impartial with respect to the association of everyday life (Potter 1997:3-4).

Understanding Democratization has been categorized into three phases: (i) the liberalisation phase, when the previous authoritarian regime opens up or crumbles; (ii) a transition phase, often culminating when the first competitive elections are held; and (iii) the consolidation phase, when democratic practices are expected to become more firmly established and accepted by most relevant actors (O'Donnell and Schmitter, 1986; Linz and Stepan, 1996 cited in Rakner, Melocal and Fritz, 2007:5). The last phase can be essential considered as function of democratic principles 
which yields good democratic governance.

On the part of democratic governance to begin with, Governance as a concept has increasingly attracted international attention. The World Bank defines governance as the "manner in which power is exercised in the management of country's economic and social resources for development" (World Bank, 2005). It relates to the processes of granting public power and the use to which such power is put, which ideally, should be for the service of the people (Imobighe, et al, 2013:244). In other words it is a reciprocal processes, in the sense that people conferred power to their representatives (managers of state power) with expectations and aspirations to "formulate and implement sound policies that will promote the corporate interest of the entire people". Meanwhile, on one hand if the government fails to conduct this obligation, then its purpose will be considered defeated, thus issues of bad governance arises. On the other hand Elaigwu (2014:244) said "good governance deals with how those who have the authority of the state make efforts to achieve the goals or the ends of the state-the maintenance of law and order, the provision of welfare for its citizens and the pursuits of national interest in the global arena".

Democratic governance therefore is a broad phenomenon that recognizes the interconnection of issues of democracy and governance. It is useful concept that touches on the significant challenges of state reform and the quest for development and progress of the people of a state. Despite this connection, democracy and governance are conceptually distinct phenomena with different theoretical and philosophical underpinnings. This is according to lbeanu and Egwu (2007), not simply because the concept of governance gained a recent entry into political discourses and was popularized by the World Bank's intervention in the debate on the African crisis in the 1980s, whereas the idea of democracy had existed since the Greek city state of Athens and came to be popularized subsequently by theory of representative democracy. They further explained that the formal, institutional and procedural elements of democracy can exist without effective governance in the sense that it does not necessarily guarantee that public officials produced by electoral process will be subjected to the norms of transparency, accountability and the rule of law. The experience of Nigeria during the intermittent periods of civilian administrations seems to support this view. Contra wise, the experience of the Asian Tigers seems to suggest, it is possible to have good governance that can advance development without democracy.

According to the Organization for Security and Co-operation in Europe (OSCE, 2011), "Democratic governance is a system of government where institution function according to democratic process and norms, both internally and in their interaction with other institutions".

The United Nations Missions (UNMIT, 2005) stated that:

The culture of democratic governance moves beyond the mere procedures of democracy and the establishment of democratic institutions. A state which identifies with the culture of democratic government is one which welcomes a wide scope of political participation embracing a pluralistic system of political parties, a vibrant civil society and media, integrating women and minorities in all levels of government, protecting right and dignity of children and involves integrated approach to sustainable governance for and by all the people (UNMIT, 2005).

In a much discussed quantitative analysis Ibeanu and Egwu, (ibid: 19), measured "democratic governance in practice, is not only expected to promote the core values of democracy, it is also about deepening democracy in such a way that state institutions and political parties are accountable to the citizens".

\section{Challenges of Democratic Governance in Nigeria's fourth republic}

In order to effectively understand the Nigeria's challenges of democratic governance in the fourth republic there is need to note that it is more than twenty years since the beginning of "third wave democratization", which has been related to 1990s influence of globalization that increase the spread democracy around the world. Meanwhile during the twenty years of increasing spread of democratization around the world, Nigeria enjoyed about fifteen years of civil rule, i.e. from 1999- 2015. During this period there were three elections which are considered as transitions from civilian to civilian i.e. 2007, 2011 and 2015 elections. The assumption is that although this period is considered as the period of "nascent democracy", yet the democratic experiment within the said period can be assessed especially in terms of the expectations and aspirations from the people of Nigeria, particularly in respect to the challenges towards fundamental principles of democratic governance. The modes of operation of this assessment is therefore centered on examining the roles of agents of globalization (transnational organizations) and the democratic institutions; within Nigeria with regard to the challenges facing democratic governance through some issues and themes in Nigeria' democracy.

A comprehensive survey of the modern nation-states political development around the world shows that they are 
formed, managed and promoted through popular struggles for the independent and sovereign development, as well as the freedom and well-being of their individual citizens (Bello, 2014:11). However, the collapse of Communism in the former Soviet Union and Eastern Europe became a particular defining moment in the sense that it signaled the resurgence of the ideas of liberal democracy across the world, popularly known as "Third Wave". Thanks to Multilateral Financial Institutions and agencies including the World Bank that, hitherto, supported "strong government" and different versions of authoritarian rule as the "guarantor" of development came to realization that without democracy, Africa's prospect for growth and development was dimmed. Thus resurgence of constitutional rule brought the new democratic opportunities in which the various constrains of democratic governance on the continent were expected to be addressed. These include, among others, strengthening the basic institutions of democratic governance such as the political parties, parliament, executive and judiciary; the sanctity of separation of powers and the rule of law; the challenge of political participation; reducing corruption in the public and political spheres; reduction and management of ethno-religious conflicts; transparency in the electoral system and the conduct of free and credible elections. However, the experience in the last two decades seems to suggest that these challenges are far from being properly addressed.

Nigeria's experience since the return to civil rule in May 1999 provides a clue for understanding the continued challenges of democratic governance. The fact that civil rule has return with constitutional framework of governance, there is little promise of democratic consolidation, because the basic institutions of democracy and governance such as the political parties, judiciary, parliament and executive remained weak and vulnerable to the manipulation of corruption, ethno-religious inclinations and personalization of power. Like other transitional societies today, Nigeria faces the challenges of transformation towards the process of democratic governance. Specifically, the challenges are visible in the state and institutions of governance which are not accountable as well as not addressing the concern for development and progress of the people. These challenges appears most critical with particular emphasis during the civilian to civilian transition between 2003-2015 in the country, where various forms of extreme personalization of power and corruption, gross human rights abuses, constitutional challenges and political exclusion of women, ethno-religious conflicts, electoral malpractice among other political vices have been compromised.

In the context of globalization of the world, the impression is often given that "democracy is good; to be undemocratic is bad" (Elaigwu, ibid: 242). However, "local politics in the global era has not only been shut down, rather it has been transformed and ... reinvigorated by the multiple identities and fluid processes of current era" (Munck: 5 cited in Grugel: 275). As Fayemi (2000:7) succinctly observed;

with the end of the cold war came economic globalization and trade integration factors that have, ironically, deepened economic problems in new democracies, weakening the nation-state and exacerbating ethno-jingoism as a result....the overriding majority of the African populace is completely detached from the democratization and there is little indication that their lot will be improved under democratization.

Indeed Nigeria has been seriously affected in the age of democratization due largely to its weakness to face the reality of sustainable development, growth and stabilization of democratic governance. Perhaps for Nigerians, survival seems to be the primary concern above any other consideration, consequently while some Nigerian (trans- nationally oriented elites) leaders in collaboration with MNC, International organizations, western countries, U.S and World Bank siphoned and looted the country's treasury, demarcated lucrative and better paying jobs for their families and their close allies within and outside the country. The under privileged people have resorted to all kinds of supplementary activities or menial jobs in order to make ends meet. As a result of worsening political and economic dislocation in the globalization era, over $70 \%$ of Nigerians are poor and lived on less than $1 \$$ per day. It is shocking revelation as Okolie revealed that life expectancy of Nigerians is 47 years (Okolie, 2003; 269). The big question on lips of many concerned people is that what is actually responsible for the weakness of Nigerian political economy? How would democratic governance be fit in inequality and deteriorating economic situations in society such as Nigeria? Does Nigeria have a way out of these crises?

Although, MNC and few countries benefit due to increasing FDI as a result of democratic dispensation, the business environment is mostly designed to benefit the powerful countries. Shah, (2011) found that due to less or lack of accountability of governments and companies in the business proceedings, some actions manifest to have encourage corruption. In fact these policies in the form of imperialism are the bedrock of globalization. They are created by international institutions, particularly the World Bank and IMF. In spite Critique of these institutions for years in regard to their role for increasing poverty through structural adjustment program, deregulation, removal of trade barriers etc. they have also created situations for corruption to grow. For example, transnational activities have strengthened the capitalist market relative to other institutions in Nigeria to such extent that it is safe to say that the market now effectively subsumes Nigerian society. For successive years the Corruption Perception Index of the Transparency International has been rating 
Nigeria as one of most corrupt nation, it is today probably the most corrupt country in the world.

Nigeria's democracy has been ultimately unstable since the return of democratic governance in 1999 in the country. "The political space has been consistently in face off with violent ethno-religious crisis and political assassinations, inter and intra-party fracas and civil disobedience" (Ogundiya 2010:231). Perhaps, Democratic governance is as earlier discussed is also a function of so many factors, including enhanced economic development, developed democratic culture, stable party system etc. "Indeed a nation inundated with corruption cannot be viable economically neither can the system generate enough affection required for the survival of democratic system. This is the situation in Nigeria where corruption has become part and parcel of the political culture". (ibid, p.235). Perhaps the culture of corruption is basically the greatest challenge Nigeria is facing, it is the shortcoming of Nigeria's polity (Olofin, 2001; Yusuf, 2001). Fundamentally, Nigeria's political culture is embellished in political corruption which manifest itself in the use of and negative influence of money in politics, election rigging and thuggery. The major form of corruption that has remained obstacle to Nigeria's national progress is the 'political corruption'. As Apam (2011:24) succinctly puts it, the way of doing politics in this context, is not to live for it but to live from it. Politicians assume the role of political entrepreneurs who invest heavily in politics with the aim of claiming super profits and dividends in the ruthless appropriation of state resources. Obuah, (2010) found that 20 percent of Nigeria's Gross Domestic Product goes to corrupt practices.

Certainly the issue of corruption scandals in the executive arm of the government or in the Parliament to support or block a motion in its plenary sessions, irrespective of the importance of that motion to ordinary Nigerians have become part and parcel of governance in Nigeria. Predominantly using secondary data Ogbonnaya, et al (2012:690) assessed that the legacy of erosion of the culture of rule of law and subsequent enthronement of the culture of arbitrariness and impunity which result to high level corruption has fundamentally impacted on power relations and democratic institutions such as the political parties, the Executive, Judiciary and Legislature as well as other agencies like Election commission. "The consequence of this has been the existence of subdued judiciary, weak oversight capacity of the legislature and dumbness of the electoral bodies both at the federal and state levels".

Despite the fact that Trans-national organizations (agents of globalization) have influenced democratization which ultimately resulted to aspiration and so-called implementation of democratic governance in Nigeria, they have done little to ensure the principles of democratic governance are duly respected. Perhaps it is no longer a news to hear that rigging, over stuffing of ballot boxes, falsification of election results or undue delay and manipulation of court judgement in many of election Tribunals in Nigeria. Indeed, the view "that the history of election administration in Nigeria is the history of electoral fraud and violence" (Ajayi, 2007) is widespread. In fact once a candidate has the money to give out to the handlers of relevant election, his name will be announce as the winner of that election. Meanwhile, this give out money usually come out from the state treasury, because if any person that has been sworn into an office while the case of his election is still hanging in the court, he can hire the best lawyers to manipulate the process in order to delay the process, especially when it is clear the outcome will not be in his favour. For instance the case of Edo and Adamawa states in 2007 governorship elections.

While busy manipulating election for a political office, Nigerian politicians as it can also be conveniently argued that at the same time they are busy dividing the larger population along ethnic and religious lines which normally result into ethno-religious conflagrations. Inter- and intra-ethnic rivalries, religious crisis and insecurity constitute imminent challenges to democratic governance in Nigeria since the return to democracy in 1999. For example, insurgency like that of Movement of Emancipation of Niger Delta (MEND) in the Niger Delta region, renewed demand for Biafara- Movement for Actualization of Sovereign state of Biafara (MASSOB) and the increasing notoriety of the Odua People's Congress (OPC) in the South- West. These crises resulted in loss of human and material resources that cannot be quantified. While the militancy in the Niger Delta took heavy toll on the nation's economy because of its independence on oil for foreign exchange earnings, the Boko haram insurgency in the North has at last count left over 16,000 policemen, soldiers and civilians including politicians dead (UNCIRF, 2012; New crime News, March, 31st, 2012 cited in Ogbonnaya, et al 2012:689).

It needs little telling to understand that what has been critically missing is the issue of democratic governance, which has to do with the way the nation's public affairs are managed and how public participate in the affairs of the state. Among the most important principles of democratic governance is the principle of participation, which is however missing in Nigerian context. While Muhammad (2014:38-9) suggests the concept of participation as collective engagement of human resources in the process of national development, he also noted that popular participation is the conscious and predetermined involvement of society in the process of governance and development. Therefore the major goal of democratic government is the provision of maximum participation through responsive and responsible government in its liberal tradition of periodic election, active involvement of civil society in decision making, development of competitive political parties and the flourishing of the rule of law. However, in the Nigerian context issues of participation have not 


\section{been given appropriate concern.}

Although existence of competitive and vibrant political parties in any polity is a sine a sine qua non for democratic governance in the fourth republic era; the role of People's Democratic Party (PDP) which has been the ruling party at Federal level since the beginning of the fourth republic until 2015 indicates direct relationship between personality and the conduct of the country's political party. As Dode (2010:1) has rightly argued that the Democratic experiment of the fourth republic in Nigeria" has not scored high when placed in the same matrix with countries that are heading towards stable democracy". He noted that while opposition political parties are expected to serve as alternative purpose where the electorate should freely choose at their wish, in Nigeria "they have been strategically weakened through the overt and covert strategies of the ruling PDP and the lack of total commitment on the part of the politicians to national course". He further avers that Nigerian political parties have today failed to deliver toward good democratic governance in terms of representation of their people, aggregating social interests as well as serving as intermediaries between state and society. This is not only because over $90 \%$ of the political parties lack credible ideology and manifestoes but also "they are fragile, they have only developed shallow roots in the society".

Judging by the situations of redundancy of democratic principles and in democratic institutions such as the three arms (Executive, Judiciary and Legislature) of government, political parties as well as the prevailing uncertainties on issues and themes in Nigeria's democracy, it is clear that there are serious challenges in the polity. This explain how rotten and decayed institutions of democratic governance look like in the country. Kaur (2007:232), assessed that "it can be said that the democratic process in Nigeria has to face challenges from the socio-economic and political arena but it is mainly due to the existence of weak political institutions that its sustenance has been made difficult". The challenges thus affects the wider scope of governance with numerous implications both internally and within global view.

It is unfortunate that Ibrahim Index of African Governance (IIAG) in 2014 rank Nigeria in the $37^{\text {th }}$ position out of 52 African countries, in overall governance with score of only $45.8 \%$.. It reveals that the country is rank the $44^{\text {th }}$ position in terms of safety and rule of law with only $38.1 \%$. The revelation further indicated that Nigeria is in the $26^{\text {th }}$ position with $48.9 \%$ in terms of participation and human rights. It has also been ranked in the $31^{\text {st }}$ with $43.9 \%$ in sustainable economic opportunity, and $34^{\text {th }}$ with $53 \%$ in human development, all within the year 2013. Perhaps it is sad to acknowledge that Nigeria in the age of today's globalization and in its fifteen years of uninterrupted civilian or the so called nascent democratic administration, it is one of the worse governed country in the world.

\section{Influence of Globalization on Democracy, Democratization and Democratic Governance}

A number of scholars describe the past four decades as a period of increasing global democratic change (e.g. Eichengreen, 2006, Huntington, 1993 and Diamond, 1992). Between 1975 and 2002 there was a quadrupling in the number of democratic countries (Eichengreen, 2006:3). Grugel, (2003:262-3) observed that large volumes of literature links globalization with issues of democratization in three unique opinions, which are; a) "globalization as the politics of democratic disempowerment; b) globalization as an opportunity for (liberal) democratic global governance; c) globalization as the radical remaking of citizenship".

In an attempt to depict and analyze the global process toward democracy in recent years, Larry Diamond's "Globalization of Democracy" (1992) briefly account the major democratic development on regions and countries in the late 1980s and 1990 with an emphasis on the developing world. He also asses this progress in quantitative terms, and advance both formal definitions of democracy and conceptual typology that permit more refined measurement. Diamond also analyzes the "leading causes of this most recent way of global democratic expansion" (Diamond, 1992:2). He concludes by submitting the prospects and conditions for democracy in the coming decade.

As an intricate social phenomenon globalization is interconnected with different parts of social life, as well as spread with ambiguities, variations, uncertainty and incompatibilities. Thus globalization produces different effects on democracy- a social phenomenon with political focus. Like the former, the latter is the outcome of social struggles or the concretization of popular power. Such concretization often has negative and positive effects, around which social forces are aligned and wage struggles (Nnoli, $2000 \mathrm{a}, 173-4)$. It is this line of argument that Philippe et al asserts that different types of democracy exists, and therefore different practices results to similarly different effects. The particular form of democracy in a particular country depends on socio economic situations and its embedded state structures and policy practices (Philippe et al 1993:40).

It is imperative to note as it is confirmed that pattern of democratization are different in different regions of the world. Between 1974 and 1990 about 30 countries made transition to democracy, it doubles the number of democracies around the globe. Thus Huntington, (1993:3) asked, "Were these signs of expanding global democratic revolution which could ultimately reach every country? Or does it represent its reintroduction to countries that have experienced it before? 
Although Samuel Huntington categorizes three different waves of democratization, the first, second and third waves, the current wave constitute the third wave of democratization. Categorization of Huntington's waves of democratization shows that:

First wave -1828-1926; examples; Italy, Germany, Argentina,

Second, short wave; 1943-62; examples, W/Germany, Italy, Japan, India, and Israel

Second reverse - 1958-75; examples: Portugal, Spain, and Numerous other in Latin American,

Asia, Africa, Eastern Europe (Cited in Potter et al, 1997).

It is well beyond the scope of this study to survey in any comprehensive way the multiple factors that have been increasing the expansion of democracy within the past waves. Rather I wish to present the key factors that contributed or give rise to 'democracy's third wave'. According to Huntington (1993) there are five significant happenings and timing of the last wave. In his words:

1. Authoritarianism and its legitimacy problem as well as its economic failures usually associated with militarism

2. Increase in education within the urban middle class in the 1960s which raise standard of living as a result of unprecedented economic growth

3. Shift of Doctrine of national catholic churches from depending the statuesque to opponents of authoritarianism

4. Policy changes, particularly from the European Community, Soviet Union and United States

5. "Snowballing" effect i.e. because it happens in one place it subsequently happens in another (Huntington, 1993:4).

Potter, Goldblatt, Kiloh and Lewis observed that "Democratization" is the main global phenomenon in the twentieth century. It spreads with particular vigor since the 1970s; in 1975 at least 68 percent of countries throughout the world were authoritarian, all the rest having held some sort of political and civil rights. In their book "Democratization" potter et al, (1997) examines, "the word Democratization refers to political change moving in democratic direction" they explained why some political regimes move in a democratic direction than others? They further explained what is meant by "moving in democratic direction and how one identify actual political regimes throughout the world as a more or less democratic".

Rudra's (2005) "globalization and the strengthening of democracy in the developing countries", like many other scholars, he assumed that "trade and financial liberalization" increases the chances of developing countries to become more democratic. However, he noted that yet there is "no developed formal hypotheses about causal relationship between globalization and democracy". Perhaps he acknowledged that the two trends are related but not in direct manner that has normally been portrayed. He uses conflict based theories of democracy and theories of embedded liberalization to depict the process that affects decisions to strengthen democracy as trade and capital flows increases. Meanwhile he argued that "increasing exposure to international export and financial markets lead to improvements in democracy if cautions are simultaneously used to strategize stability and political support".

Perhaps, it is not surprising when Moghadam (2005:35) perceived "Political globalization", as an increasing trend toward multilateralism (in which the United Nations play a key role) toward an "emerging transnational state apparatus and toward the emergence of national and international non-governmental organizations that act as watchdogs over governments and have increased their activities and influence". In the same vein, Held (1999:35) refers to political globalization as to increasing number and power of human associations which "influence or govern the world as a whole due to the increase of Inter-Governmental Organizations (IGOs) and International Non-Governmental Organizations (INGOs)". Whereas there were 37 IGOs in1909 by 1996, they were 260, and there were 176INGOs in 1909 by 1996 they became 5,476 .

\section{Challenges of Globalization on Democracy, Democratization and Democratic Governance}

In demonstrating that the phenomenon has been increasing democratization, it is also the main challenge of democratic governance, Scholte (2005b) like many others who observed globalization in relation to democracy from the critical viewpoints, he stated that the phenomenon has caused the state form of governance not to live and develop on its own and it encouraged the emergence of many centres of regulation. He explain that although "globalization has impacts on several forms of social stratification, including, age, gender, class race, urban/rural divides, country and (dis) ability; it has contributed to slim social hierarchies in certain respects, certainly the process has widened gaps in life chances structurally" (p. 316).

He further explained that the conventional framework of liberal democracy, which focus on nation's territorial selfdetermination, is not an adequate formula for rule by the people in the multi-centred governance of a more global world. 
He also posited that the wide ignorance among citizens about globalization and its governance has severely restricted the possibilities for democratic regulations of trans-planetary relations. He thus criticised that across state, sub-state, suprastate and private regulatory institutions, the decision making process that govern globalization have shown major shortfalls of public participation and accountability. This resulted to deeply entrench structural inequalities which have highly skewed opportunities of citizen's involvement in the governance of contemporary globalization (p.248). He however assessed, globalization is considered to be a "macro-sociological aggregative fact" which undermines the achievements of democracy due to the fact that the proper relations between "decision takers and decision makers" is missing. The phenomenon is considered as a burden on democracy as it is pursued in "existing liberal representative systems" (ibid; 134). Similarly, Grugel (2003:271) stressed "global governance agencies not only do little to alleviate the problems faced by a majority of the world's population or to guarantee the conditions for global peace and democracy; they are themselves a source of inequality. This is the case as far as the World Trade Organization (WTO) and International Monetary Fund (IMF)".

Porta (2006) noted that growing influence of International Governmental Organizations supporting democratization, if not consolidation of democracy. Porta (ibid, 670) said economic features of globalization are indeed increasing growing interdependence which shows production is being moved to countries with lower wages. It pushes large number of peoples from under developed south and east to developed north and west. It also shows growth of MNC in late "1990s controlled $20 \%$ of world production, $70 \%$ of global trade and $80 \%$ of Foreign Direct Investment". He further affirmed that the phenomenon does not resolve global inequalities, and that with economic aspects of globalization, the state renounce its repressive powers and therefore consider globalization as "involution of the state".

He also observed significant cultural changes in the globalization era, as a result of interdependence in "today's world" and the shortening of time and space through "communication processes that affects the production and reproduction of cultures via organization of social relations and transactions assessed in terms of extension, intensity, velocity and impact". In terms of democracy he pointed that globalization confirmed that the only legitimate regime recognize today is democratic regime. He noted the debate among scholars that while others consider the trend as imperialism, others consider today's global culture as the product of the cosmopolitan and the rich. He further observed the danger of cultural globalization as a result of one "single way of thinking since the collapse of Socialism, US and its allies enact policies to mitigate inequalities of the capitalist model; and also limited the number of strategic options open to countries in the south of the world" (ibid, 673).

Indeed, globalization represent a challenge for social movement, it increases conflict at both national and transnational levels, increase unemployment particularly that of job insecurity and hazardous working environment. Porta (ibid, 675) added that the phenomenon generated protest against "destruction of physical habitat", and the re-emergence of varieties of nationalism, ethnic movement, religious mobilization and Islamic fundamentalism are thus reaction to alien cultures and values. In the same trend while cultural aspects of globalization endangers national identity, new technologies also serves to ease communication around the world via media that escape normal censorship. Meanwhile cultural, political and economic systems witnessed increasing of interaction that aggravated new conflicts and also opportunities for expressing these conflicts at multi-territorial levels to the extent those international organizations such as WTO, NAFTA, and GATT are targeted. Perhaps since the 1999 Seattle anti-globalization protest, the movement increasingly continued in different summits around the globe challenging IGOs, such as IMF, World Bank and EU. He also interpreted that liberal market economic system is driven by US and other international financial institutions- the IMF. WTO and World Bank. Thus deregulation and privatization are seen as tactics enshrined by international financial organizations and governments of the rich nations, particularly the group of eight (G8) and the group of seven (7) to the benefit of MNC.

Therefore globalization is not only a matter of mode of increasing production and new technology, but also the political tools set to reproduce and regulate this system through, among others, the spread of IGOs that governs processes that can no longer be handled by national governments. It is thus not surprising because after the second world war there has been increase in worldwide scope of IGOs-"the number rose from 37 to 309 between 1909 and 1988 and the number of IGO conferences from a couple per year in the $19^{\text {th }}$ century to close to 4,000 annually at the end of the $20^{\text {th }}$ century" (ibid, 680).

In his recommendations to the problems described above Porta, suggests, if pertinent global problems should be handled within the democratic enclave, there should be "political representation of citizens in global affairs independently and autonomously of their political representation in domestic affairs". He propose "cosmopolitan democracy, requires democratic states but also democratic supra-national institutions". He suggest reform of existing IGOs including reorganization of leading UN institutions, such as the Security Council in order to "increase the power of developing countries". The need for second UN chamber for participation of representative of civil society, other recommendations 
include representation in the UN of both opposition groups and national governments; limitation or abolishing of veto power "subordination of international financial institutions to the UN General Assembly"; as well as reform of IGOs on the basis of the principle of one- state- one-vote. In the long term he proposed reforms to include the creation of "Global Parliament" as well as strengthening of international political system.

It is noteworthy to observe that democratization requires political freedom from the state; freedom to speak organized and protest. Perhaps, aspiration of democratization rest squarely towards achieving democratic governance where principles of democracy should be functioning and operationalized within democratic societies. Democratization is thus processes of struggle over democratic objectives, and has remained a major issue in globalization. And the impact of the struggle over democratic objectives has largely manifested in the political history of the transitions toward democracy. However, the manifestation of this struggle has been condemned as "the hunting menaces of a cultural homogenizing globalization that immiserates billions of people and promises politically sterile and enfeebled forms of democracy". Matusik argues such democracy is one possible outcome of the multidimensional forms of identity fostered by the new world order endangered by globalization. Rather than see fragmented identities and fractured loyalties he conceives of "post national identities" that overcome the narrowly partisan construction of nation, race, gender, religion, and such. He also tells a story about stories. The first story, trumpeted in the first world, hails the apparent victory of liberal democracy and free marketeering since 1989. A second story recounts the increasing social, political economic and cultural exploitation caused by flaccid democratic arrangements and culturally homogenizing effects of integrated global markets. This is the story from the margins and from impoverished third world and fourth world. A third tale outline the prospects for new political and economic forms that heighten multicultural democracy in the light of the overlapping and invented identities arising from the complexity and heterogeneity embedded in global relations (cited in Burch , 1998:123). However, Burch has noted, this tell is obscured by the naiveté and gloom, respectively, of other stories.

But relating to exploitation caused by flaccid democratic arrangements and the culturally homogenizing effects integrated global markets, Nnoli also, assessed while the earlier form of globalization, exemplified by colonialism, created an undemocratic state structure, which Africans have waged a relentless struggle to democratize, the contemporary form is abolishing the state as the focus of that struggle. It is thereby rendering democracy irrelevant. He observed that over the year's democratic struggle have been waged over the following objectives.

1- The distribution of material power

2- The incorporation of excluded social groups in to the political process

3- The right of citizen or the struggle for the promulgating of the bill of rights

4- The rule of law including access to the law has been useful in the struggle against tyranny.

5- Elections, including how people emerged as candidates, Elections have to be free and fair to contribute to the democratic process.

6- The effort to separate and balance powers

7- The quality of democracy depends a lot on how parties are formed and who finance them.

8- The extend and quality of popular participation in the governmental process,

9- Active involvement of public opinion

10- Government's responsiveness to public opinion (Nnoli, 2000a: 175-6).

However, globalization is spreading the value of liberal democracy, which restricted to multi-party elections. Unlike the democracy of popular empowerment this globalized democracy is not threatening to the rulers. It is therefore not the basis for popular pressure on the regime to respond to the interests and needs of the people. This is why every African regime is embracing multi-party democracy, including the most tyrannical regimes. It provides them with international respectability without constraining their absolute authoritarianism, corruption and ineffectiveness at home. It does not require the reform of the inherited and repressive state structure and does not needs to address the problems of the poor, such as poverty, ignorance and disease, which constrain them from effective political participation in multi-party elections (Nnoli, 2000a: 180). Moreover globalization has aided the growth of liberal democracy in Africa and elsewhere in the world. Since the end of the Cold war liberal democracy seems triumphant and unchallengeable. The task of globalization is to universalize it. The international community, led by the only surviving super power, the US, is championing its cause and using its control of the media and economic resources to promote it. Meanwhile, development discourse now focuses primarily on how to liberalize markets and democratize societies the American way.

It therefore pertinent to note that despite the positive impact of the influence of globalization towards the spread of democratization, it poses challenges to principles of democratic governance. For instance, on the one hand, according to the managing Director of IMF (2002) "globalization represents a political choice in favor of international economic integration, which for the most part has gone hand-in-hand with the consolidation of democracy". On the other hand, according to Hay (2011: 312) the challenge of the phenomenon on the "accountability, autonomy, capacity and 
sovereignty of the nation state is put to question". Perhaps the democratic character of governance in contemporary societies is at stake. He added that "globalization of politics is displacement of political capacities and responsibilities from the national level to the genuinely global level, through the development of institutions of global governance" (ibid: $p$. 314).

\section{Conclusions}

A democratic governance run for and by a people with the problem describe above surely has inherent seed of destruction. This is because it is dealing with degenerate potentials that are so ignorant and easily manipulated by unscrupulous politicians seeking their selfish ends. Therefore identifying and assessment of these challenges as they affect Nigeria especially as they affect democratic process is critical in outlook. Thus impartial application of rule of law such as penalising offenders in respect to the provision of the constitution would serve as deterrence not to subvert democratic processes or the general development of the country

After an assessment of the feature of the fourth republic era, the paper suggest that the only reliable recommendation, therefore is to allow democratic principles of governance to take its course. This means the attitudes of Nigerians must concur with democratic principles. The expectation is that the attitude of any public or political office holder would help in actualization of having viable strong democratic institutions. After all if attitudes and institutions stand strong the issue managing resources would naturally manifest accountability and transparency.

\section{References}

Ajayi, K. (2007): Elections Administration in Nigeria and the Challenges of 2007 Elections, The Social Sciences, Medwell Journals, 2 (2), $142-151$

Apam, J. (2011): Consolidating Democracy in Africa: Between Credible Election and Governments of National Unity. Journal of Democratic Studies. Vol.3, 17-38

Bello, S. (2014): Challenges and Opportunities in Nation-Building and Democratic Governance: Perspectives on Politics in Nigeria, Bello, S. and Yusuf, M.M (Ed) in Popular Participation and Democratization in Nigeria under the Fourth Republic, Africa Research and Development Agency (ARADA). Ahmadu Bello University Press Limited, Zaria, Kaduna State, Nigeria, 11-28.

Burch, K. (1998): Stories of Menacing Globalization, American Journal of Islamic Social Sciences- (AJISS) Vol. 15 No. 13, 119-128.

Diamond, L. (1992): Globalization of Democracy: Trends, Types, Causes and Prospects, Centre for Democratic Studies. Fena Typesetters and Graphics Limited.

Dode, R. (2010): Political Parties and the Prospects of democratic Consolidation in Nigeria: 1999-2006. African Journal of Political Sciences and International Relations. Vol. 4 (5), 188-194, @ http://www.academicjournals.org/ajpsir

Ebirim, S.I (2014): The Effects of Electoral Malpractices on Nigeria Democratic Consolidation (1999-2003). Public Policy and Administration Research, Vol. 4 No. 2, 49-54, @ www.iiste.org.

Elaigwu, J.I. (2014): Democracy and Democratic Deficits, Elaigwu, J.I (Ed) in Federalism Democracy in Nigeria: Fifty years After, Institute of Governance and Social Research (IGSR), 242-256.

Fayemi, J.K (2000): Beyond Presentability: Civil-Military Relations and the Future of Democratic Consolidation in West Africa. Centre for Democracy and Development (CDD) 12, The Leather market, Weston Street London SE1 3ER, UK

Grugel, J. (2003): Democratization Studies in Globalization: the coming of age of a paradigm, British Journal of Politics and International Relations, Vol. 5, №.2 May 2003, 258-283

Hay, C. (2011): Globalization's Impact on States, Ravenhill, J. (Ed), in Global Political Economy, Third edition, Oxford University Press, London.

Held, et al (1999): Global Transformations: Politics, Economics and Culture, Stanford University Press, California.

Huntington, S. (1993): Democracy's Third wave, Diamond, L. and Plattner, M.G (Ed) in The Global Resurgence of Democracy, The John Hopkins University Press, Baltimore and London.

Ibrahim Index of African Governance (IIAG) 2014

IMF, (2002): Globalization: A Framework for IMF Involvement, This Issues Brief based on a speech, "Working for a Better Globalization", given by the Managing Director of the IMF at the United States Conference of Catholic Bishops in Washington D.C. on January 28,2002 . The speech is available at http://www.imf.org/external/np/speeches/2002/012802.htm.

Imobighe, T. A (2003): Peace and Conflict Resolution in a Democratic Nigeria. A Paper presented at the fourth annual conference of the Full Bright Alumni Association of Nigeria (FAAN) National Institute for Policy and Strategic Studies (NIPSS) Kuru, Jos, Nigeria.

Kaur, S. (2007): Institutional Development as Challenge to Democratic Sustenance in Nigeria, International Studies, 217-233, available @ http://isq.sagepub.com/content/44/3/217.refs.html

Moghadam, V.I. (2005): Globalizing Women: Trans-national Feminist Networks. Baltimore, MD: The John Hopkins University Press

Muhammad, H. (2014): Popular Participation for Sustainable National Democratic Development, Bello, S. and Yusuf, M.M (Ed), in Popular Participation and Democratization in Nigeria under the Fourth Republic, Africa Research and Development Agency (ARADA). Ahmadu Bello University Press Limited, Zaria, Kaduna State, Nigeria, 34-47. 
Nnoli, C. (2000a): Globalization and Democracy in Africa, Nabudere D. (Ed), in Globalization and Postcolonial State, APP Books Harare Zimbabwe Publishing, $73-89$

Nnoli, C. (2000b): Globalization and Politics in Africa, in Government and Politics in Africa, Nnoli, O (Ed), Zimbabwe, AAPS Books, 887903

Obuah, E. (2010): "Combating Corruption in a "Failed" State: The Nigerian Economic and Financial Crimes Commission (EFCC"). Journal of Sustainable Development in Africa (Volume 12, No.1, 2010) http://findarticles.com/p/articles/mi_hb6608/is_1_12/ ai_n56814373/.

Ogbonnaya, U. M. (2012): The Challenges of Democratic Governance in Nigeria's Fourth Republic, National Institute for Legislative Studies (NLS), Nigeria.

Ogundiya, S. I. (2010): Corruption: The Bane of Democratic Stability in Nigeria, Current Research Journal of Social Sciences, 2 (4): 233-241.

Okolie, A. (2003): Globalization and the Challenges of Development of Nigeria's Political Economy, Akpan, O.U (Ed) in The Art and Sciences of Politics, Essays in Honor of Alhaji Ghali Umar Na'abba, Footsteps Publications, Port Harcourt, 263-275.

Olofin, E. A. (2001): Corruption and Governance in Nigeria, Proceedings of a Round Table Discussion, Organized by Centre for Democratic Research and Training, Mambayya House, Bayero University, Kano, Nigeria.

Organization for Security and Co-operation in Europe (OSCE, 2011): Office of Democratic Institutions and Human Rights. www.osce.org/odihr/demgov

Philippe, C. et al (1993): What Democracy is and is not, Diamond L. and Plattner M.F (Ed), in Global Resurgence of Democracy, The Hopkins University Press. Baltimore and London, 39- 52.

Porta, D.D. (2005): Globalizations and democracy, Democratization, 12:5, 668-685, DOI: 10.1080/13510340500322140@ http://www.tandfonline.com/doi/pdf/10.1080/13510340500322140

Potter, D. et al (1997): Democratization, Polity Press.

Rakner, L. Menocal, A.R and Fritz, V. (2007): Democratization's Third Wave and the Challenges of Democratic Deepening: Assessing International Democracy Assistance and lessons learned, Research Project (PR-05-GG) of Irish Aid on Good Governance, Aid Modalities and Poverty Reduction: Linkages to Millennium Development Goals and Implications for Irish Aid.

Report of the Electoral Reform Committee (2008)

Rudra, N. (2005): Globalization and the Strengthening of Democracy in the Developing World, American Journal of Political Science, Vol. 49 N0 4, 704-730 @ http://www.jstor.org/stable/3647692.

Scholte, J.A (2005): The Sources of Neo-Liberal Globalization, Overarching Concerns Program Paper No. 8, United Nations Research Institute for Social Development (UNRISD).

United Nations Mission in Timor (2005) Unmit.unmission.org/globalissues/democracy/democracy-and-un.html

Williams, A. (1995): The fictionalization of Democratic struggle in Africa: The Nigerian Example, Olowu, O. et al (Ed) in Governance and Democratization in Nigeria, Spectrum Books, Ibadan.

World Bank, (2005): Explaining inclusion: disability and community driven development, Social Development Notes 33013, community driven development, No. 100 (May) 